\title{
Review on Chemical Constituents and Biological Activities of Genus Anthemis
}

\author{
Rima Boukhary*, Maha Aboul-ElA, Abdalla El-Lakany
}

Rima Boukhary*, Maha AboulEIA, Abdalla El-Lakany

Department of Pharmaceutical Sciences, Faculty of Pharmacy, Beirut Arab University, 115020 Beirut, LEBANON.

\section{Correspondence}

\section{Rima Boukhary}

Department of Pharmaceutical Sciences Faculty of Pharmacy, Beirut Arab University, 115020 Beirut, LEBANON

E-mail: boukharyrima@yahoo.com

History

- Submission Date: 05-05-2019;

- Review completed: 17-05-2019;

- Accepted Date: 24-05-2019.

DOI : 10.5530/pj.2019.11.180

Article Available online http://www.phcogj.com/v11/i5

\section{Copyright}

(C) 2019 Phcogj.Com. This is an openaccess article distributed under the terms of the Creative Commons Attribution 4.0 International license.

\begin{abstract}
Genus Anthemis of Family Asteraceae contains mainly flavonoids, sesquiterpene lactones belonging to germacranolides, eudesmanolides, guaianolides, sterols and essential oils. The Plants of genus Anthemis have been known to have anti-inflammatory, hepatoprotective and antioxidant activities due to their rich contents of important physiological and biological compounds. They are referred to as nature's biological response modifier's and are involved in energy transfer, photosensitization and morphogenesis. Several clinical studies have shown that people who take diets rich in flavonoids and sesquiterpenes have reduced risk of developing cancer and cardiovascular diseases. This article covers most of constituents of plants of genus Anthemis reported from 2002 up to 2018. Furthermore, the biological activities of plants of genus Anthemis will be presented.
\end{abstract}

Key words: Anthemis, Flavonoids, Sesquiterpenes, Anti-oxidant, Anti-inflammatory.

\section{INTRODUCTION}

Genus Anthemis comprises approximately 210 species 51 of which belong to Turkish flora. Anthemis is a genus of aromatic flowering plants closely related to Chamaemelum which is known as chamomile. Some species are also called dogfennel or mayweed. They are endogenous to the Mediterranean region and southwest Asia east to Iran. A number of species have also become naturalized in the United Kingdom and other parts of the world. ${ }^{1,2}$ The Anthemidinae consist of the genus Anthemis with conditional addition of the monotypic genus Nananthea DC. ${ }^{3}$ All have a tiny, chaffy scale between each two florets, which is very small and is considered as a main feature of the genus Anthemis. The diameter of capitula is $8-20 \mathrm{~mm}$; the receptacle is solid and its base is surrounded by an involucres comprising 2-3 rows of compact and imbricated bracts with scarious margins. All florets are ligulate, but a few pale yellow tubular florets occur in the central region. Ligulate florets are white, dull, lanceolate and reflexed with a dark brown, inferior ovary, a filiform style and a bifid stigma; tubular florets have a five-toothed corolla tube, 5 syngenesious, epipetalous stamens and a gynoecium similar to that of the ligulate florets. ${ }^{2,3}$

The genus Anthemis is characterized mainly by the presence of sesquiterpene lactones, belonging to germacranolides, eudesmanolides, guaianolides and flavonoids. ${ }^{4-6}$ Constituents of Anthemis species were proven to exert anti-inflammatory, hepatoprotective and antioxidant activities. ${ }^{7,8}$ Anthemis species are commonly used in folk medicine in the treatment of gastrointestinal disorders, hemorrhoid, dysmenorrhoea and stomach ache in Turkish traditional medicine..$^{9-11}$ Extracts, tinctures, salves and tisanes from both aerial and root parts are used as antibacterial, antispasmodic and for the treatment of inflammatory diseases in Europe. ${ }^{12,13}$ In June 2014, Yusufoglu et al. evaluated the antiinflammatory and hepatoprotective properties of Anthemis scrobicularis in rats against carrageenan induced inflammation and carbon tetrachloride $\left(\mathrm{CCl}_{4}\right)$ induced hepatic injury. ${ }^{14}$ They found that this plant plays an important role in increasing the curative capacity of kidney and liver. In 2014 Bardaweel et al. reported that, Anthemis palestina exhibited antioxidant and anticancer activities due to the presence of flavonoids. ${ }^{15}$ Moreover, it was reported to be active against MCF7, MDA-MB-468 and UACC-257 cancer cell lines. ${ }^{16}$

Researchers are still working on determining the biological activities of flavonoids playing an important role in curing and preventing several health ailments such as cardiovascular diseases, diabetes and cancer. ${ }^{17,18}$ Antioxidants are compounds that protect cells against the damaging effects of reactive oxygen species due to reactions with DNA, proteins and lipids. Flavonoids have been found to have an additive effect to endogenous scavenging compounds and because of their potential therapeutic significance, the number of identified flavonoids is increasing rapidly and extensive screening of their actions is being carried out in many laboratories. ${ }^{19,20}$ This article deals with the previously separated sesquiterpenes and flavonoids isolated from a variety of Anthemis plants and published in periodicals, monographs and other related sources during the period 2003 till 2018 as shown in Tables 1,2 and 3. Moreover, examples of illustrative photos of Anthemis species growing in Lebanon are shown below in Figures 1 and 2.

It has been reported that different parts of Anthemis plant (leaf, stem, root, seed) contain many constituents including flavonoids, sesquiterpenes, carboxylic acids and other phytoconstituents possessing diverse pharmacological properties. ${ }^{19,20}$ 
Table 1. Previously isolated sesquiterpene lactones from genus Anthemis.

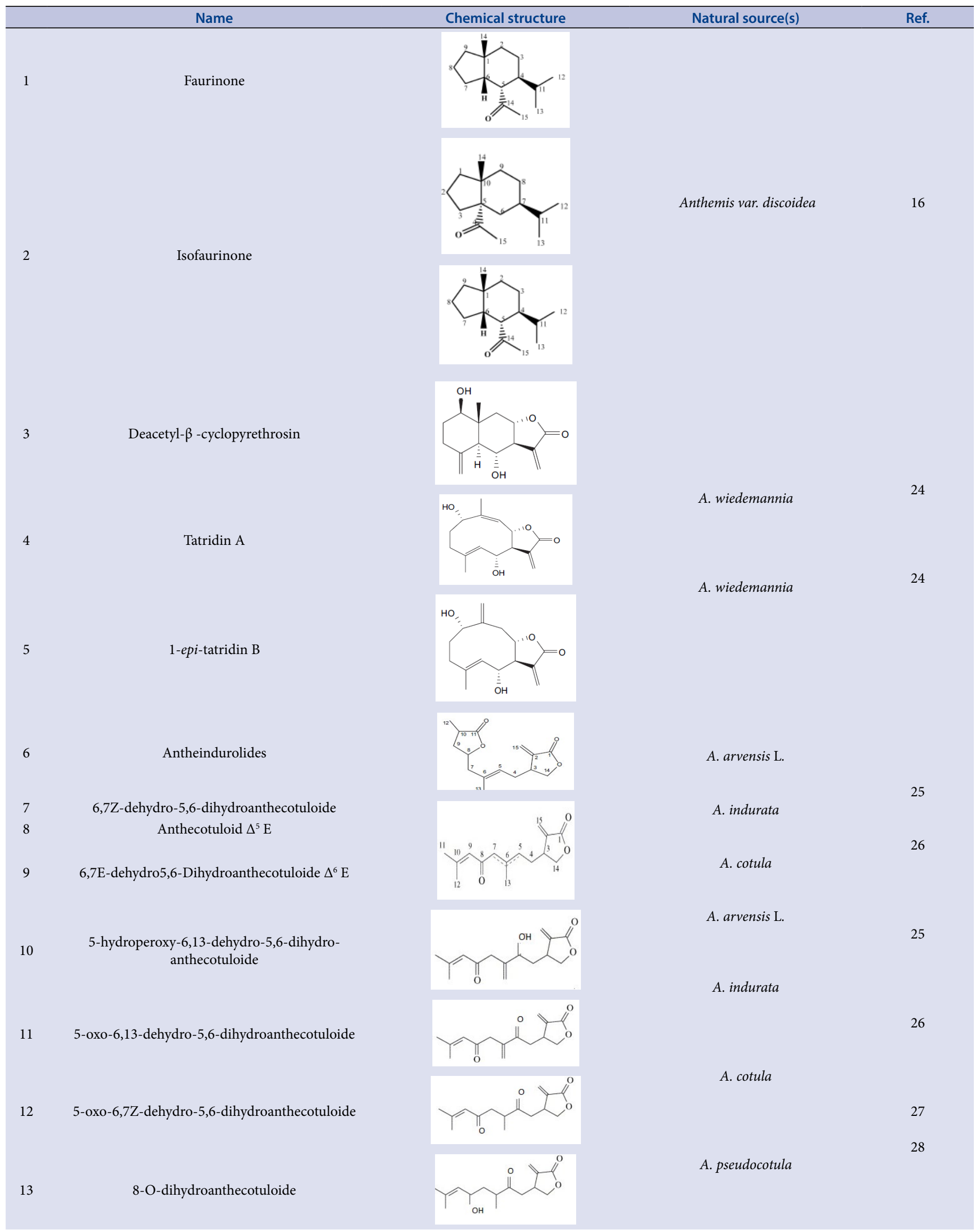




\begin{tabular}{|c|c|c|c|c|}
\hline & Name & Chemical structure & Natural source(s) & Ref. \\
\hline 14 & Antheindurolide B & & & \\
\hline 15 & $\begin{array}{l}\text { 2,10-Dihydroxy-8-angeloxy-9-acetoxyguaia-3,11(13)- } \\
\text { diene-6,12-olide }\end{array}$ & & A. alpestris & 29 \\
\hline 16 & Sivasinolide & & A. altissima & \\
\hline 17 & Altissin (Desacetyl Bcyclopyrethrosin ) & & & 30 \\
\hline 18 & Tatridin-A & & & \\
\hline 19 & 1-Epi-tatridin B & & & \\
\hline 20 & 1R,10B-epoxy-6-hydroxy-1,10H-inunolide & & & \\
\hline 21 & $\begin{array}{c}4 \alpha, 9 \alpha \text {-Diacetoxyguaia-2, } 1(10), 11(13) \text {-trien-12, } \\
6 \alpha \text {-olide. }\end{array}$ & & & \\
\hline 22 & $\begin{array}{c}\text { 1 } \alpha, 4 \mathrm{~B} \text {-dihydroxy-11H } \alpha \text {-guaia-2, 10(14)-dien-12, } 6 \\
\alpha \text {-olide. }\end{array}$ & & & \\
\hline 23 & Nobilin & & Anthemis nobilis $\mathrm{L}$. & 20 \\
\hline
\end{tabular}


Table 2. Previously isolated flavonoids from genus Anthemis.

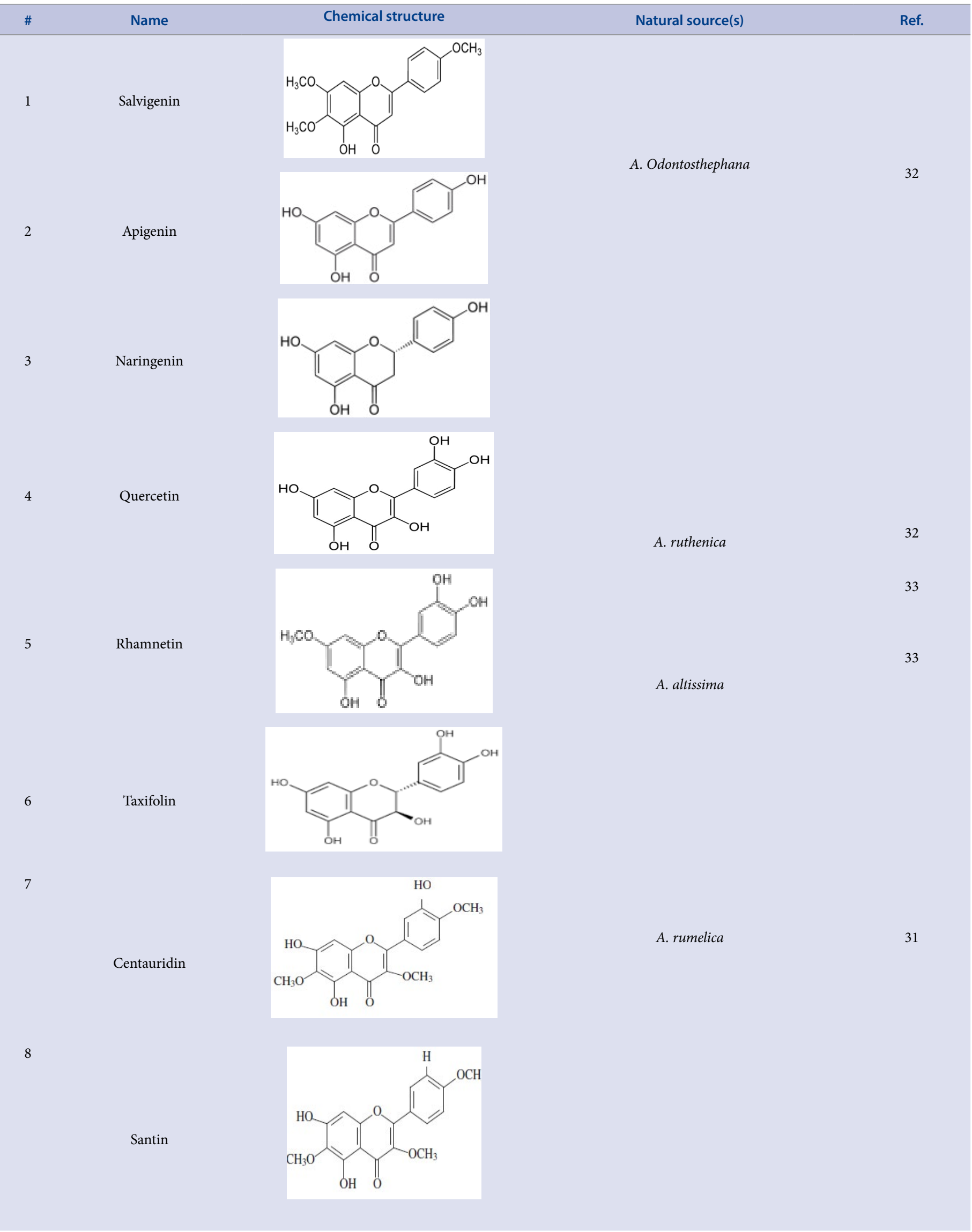




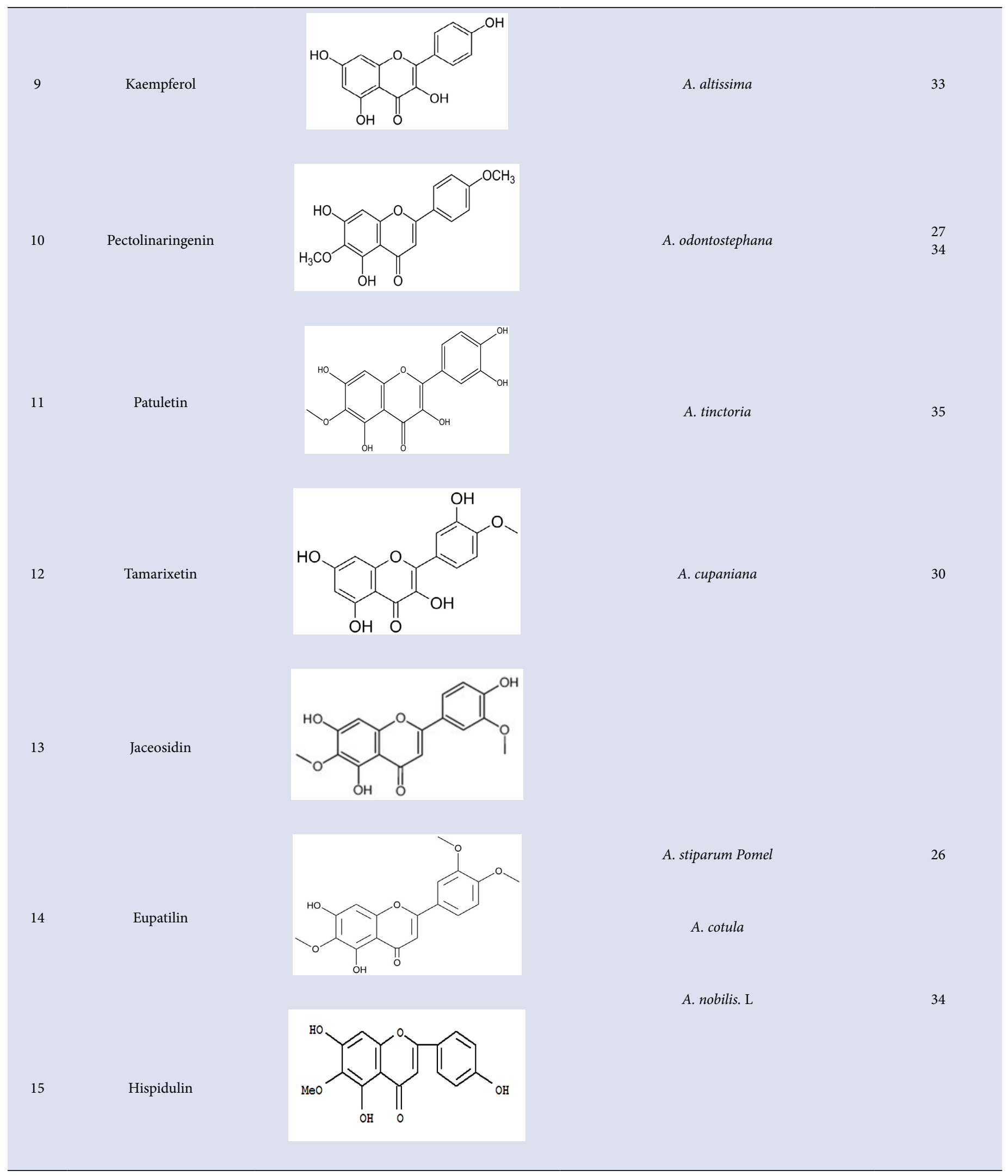


Table 3: Previously isolated phenolic acids from genus Anthemis

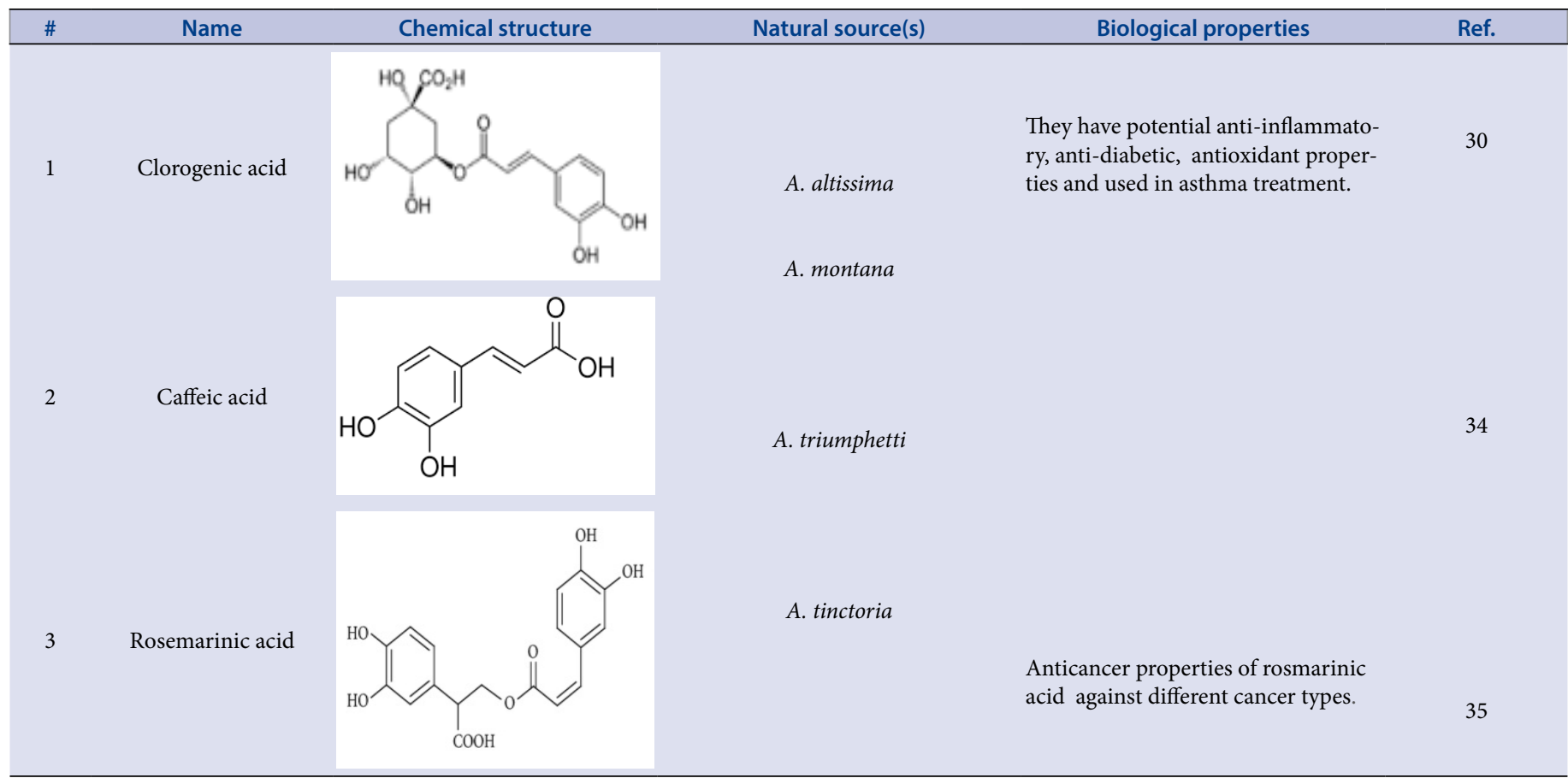

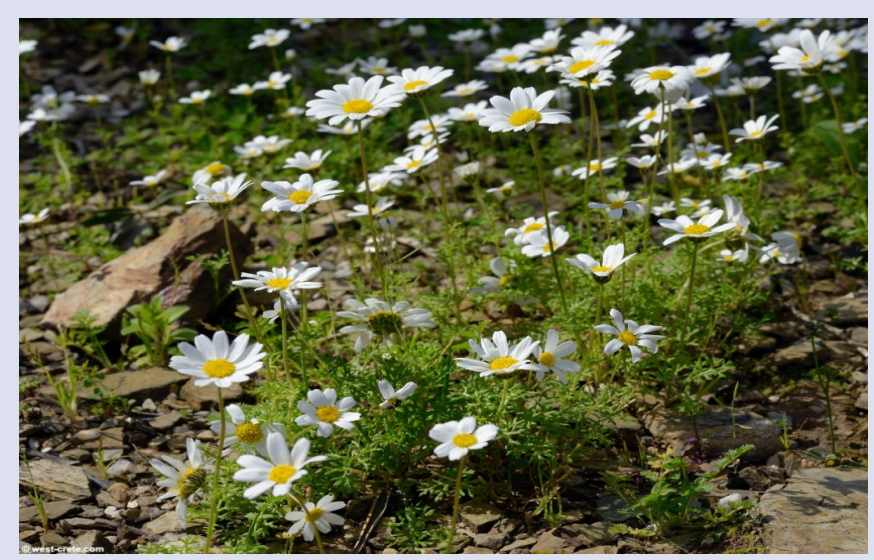

Figure 1. A photograph of Anthemis chia. L.

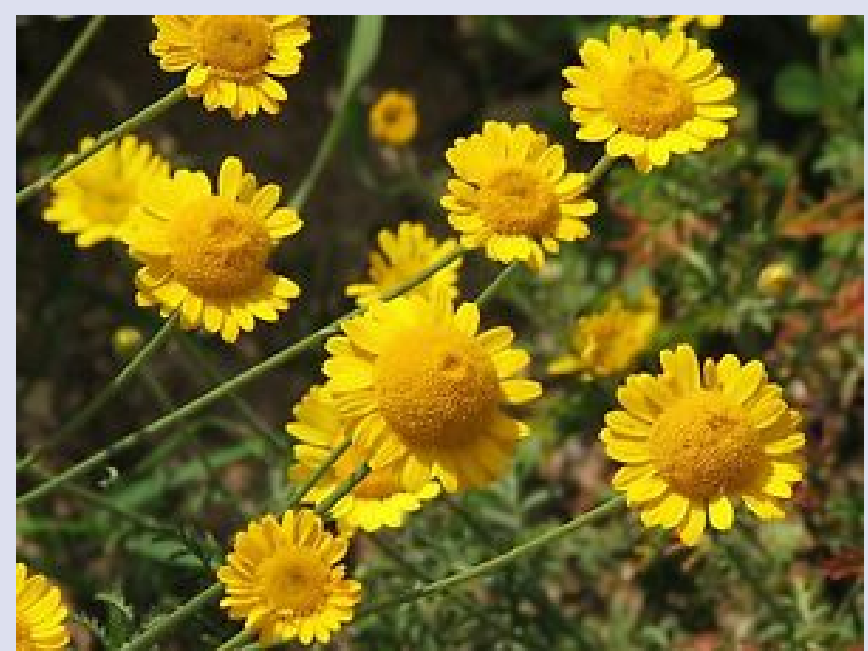

Figure 2. A photograph of Anthemis tinctorial. 
Compounds were identified by HPLC, Gas chromatography NMR, MS and UV. The chemical structures of the constituents of the plants of Genus Anthemis are presented in Tables 1, 2 and 3. Their different biological activities will be proved in the following paragraphs.

Sesquiterpene lactones have a distinctive biological activity connected to the presence of $\alpha, \beta, \gamma$ unsaturated lactone ring and are a class of naturally occurring plant terpenoids representing a diverse and unique class of natural products. ${ }^{19,20}$ They are important constituent of essential oils, which are formed from head-to-tail condensation of three isoprene units and subsequent cyclization and oxidative transformation to produce a cis or trans-fused lactone. ${ }^{19-21}$ These secondary compounds are primarily classified on the basis of their carbocyclic skeletons into pseudoguainolides, guaianalides, germanocranolides, eudesmanolides, heliangolides and hyptocretenolides etc.

Twenty three sesquiterpene lactone were obtained from different Anthemis species especially from Anthemis arvensis, A. endurata, A. cotula and A. pseudocotula. In addition, the literature revealed the presence of 17 flavonoids abundant in different species especially in A. altissima, A. cotula and $A$. nobilis along with phenolic acids like rosemarinic and caffeic acids isolated from A. triumfetta, A. altissima and other species. ${ }^{19-21}$

Anthecotuloide is an irregular sesquiterpene lactone isolated from A. cotula L. Its expected biosynthetic pathway was via two pathways, either a Non-Farnesyl Diphosphate (FPP) Route or by head to head condensation of geranyl diphosphate with dimethylallyl diphosphate. ${ }^{21}$

Rosmarinic acid is an acid esters widely found in plants belonging to family Asteraceae in several Anthemis species and considered as a defense compound. ${ }^{22,23}$ Moreover, the most probable biosynthetic pathway of rosmarinic acid is shown in Figure 3.

\section{DISCUSSION}

The genus Anthemis is characterized mainly by the presence of flavonoids, sesquiterpenes and phenolic acids. ${ }^{17,18,29}$ This literature survey revealed the isolation of 23 sesquiterpene lactones and 17 flavonoidal compounds from several species of Anthemis mostly from cotula, wiedemannia and altissima and are responsible for diverse biological activities. Anthemis chia is used in Lebanese

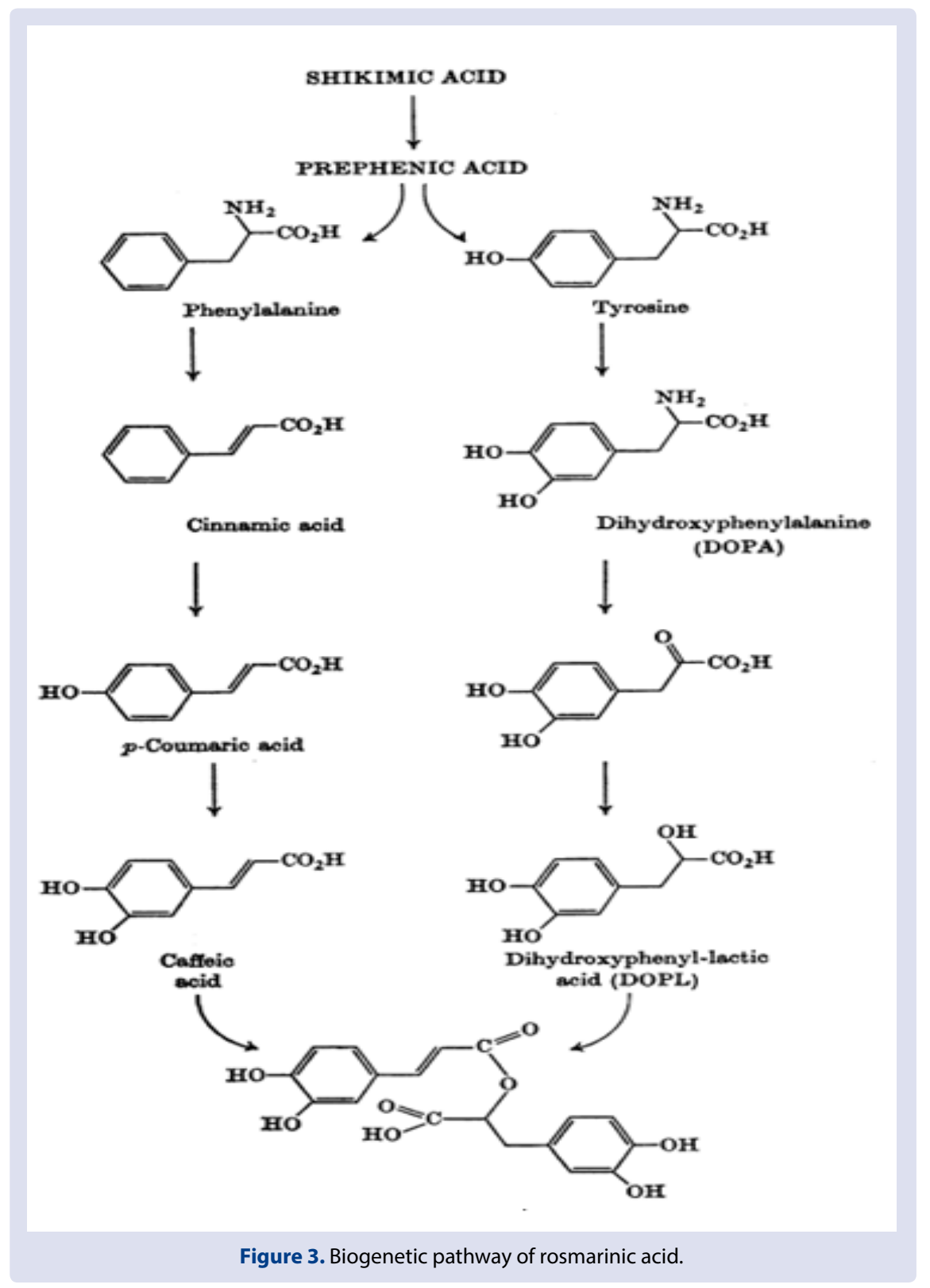


folk medicine due to its anti-inflammatory activity antifungal and anthelminthic action as well. ${ }^{24}$ This genus is used as febrifuge for diarrhea and dysentery. Decoctions prepared from flowers are also used as insecticide and as emetic while the herb as a whole is used mainly for herb beers preparations and for external use in toothache, neuralgia and earache. ${ }^{13,25}$

Sesquiterpene lactones SL are terpenoid compounds characteristic of the Asteraceae (Compositae) and possess a broad spectrum of biological activities, ranging from anti-inflammatory, phytotoxic, antibacterial, and antifungal to cytotoxic/anticancer. Various sesquiterpene lactones SL are known to be toxic to human and animal parasites, insects and vertebrates. ${ }^{19,20}$ Therefore, they can induce apoptosis of cancer cells and affect intracellular redox sign. In recent years, anticancer properties of these compounds and molecular mechanisms of their action have been studied extensively on numerous cell lines and also on experimental animals. ${ }^{19}$ They have been shown to disrupt cellular redox balance and induce oxidative stress in cancer cell. Previous chemical studies seem to indicate that SL patterns are systematically important within the genus and have been described in 30 papers. The first literature report refers to the bitter sesquiterpene lactone nobilin from Anthemis nobilis $\mathrm{L} .{ }^{20}$ Apart from unusual acyclic lactones isolated from Anthemis cotula L. and the untraditional open chain sesquiterpene lactones previously isolated from the aerial parts of Anthemis pseudocotula growing in Egypt. ${ }^{28}$ Other Anthemis species contain representatives of three major types of sesquiterpene lactones: germacranolides, eudesmanolides and guaianolides.

Anthemis species have been used for the treatment of gastrointestinal disorders, hemorrhoid, stomach ache, Helicobacter pylori and inflammatory diseases in Turkish folk medicine. Extracts, tinctures, salves and tisanes are used as antibacterial, antispasmodic and for the treatment of inflammatory diseases in Europe..$^{23}$ Moreover, it is used in Lebanese traditional medicine against abdominal pain, urinary infection and as sedative. ${ }^{26,27}$ It is also used for the treatment of cough and cold and as antifungal. ${ }^{27}$ The antioxidant activity has been the subject of many researches. ${ }^{30}$

In addition, $A$. tinctoria and $A$. triumfeti act as defensive agents and exert different biological activities such as anti-inflammation, antiproliferative and inhibitory tumor cell growth. ${ }^{30,31}$ Anthemis scrobicularis exerted nephroprotective and hepatoprotective activities due to the free radical scavenging activities of its flavonoidal constituents. ${ }^{32} \mathrm{NMR}, \mathrm{MS}$, IR and UV studies revealed the structure of several compounds isolated from Anthemis genus such as rhamnetin and taxifolin obtained from $A$. altissima as shown in Table 2.

\section{ANTI-INFLAMMATORY ACTIVITY}

Turkey, Anthemis species are used in folk medicine due to their antiinflammatory activities and antifungal activity too. ${ }^{35-37}$ Several literature proved that Anthemis species like A. triumfeti and A. tinctoria rich in fatty acid content showed antiinflammatory effects. Fatty acids are known as self defensive agents in organisms and possess various biological activities including anti-inflammation. ${ }^{36,37}$ Linalool, 1, 8 cineole and hexadecanoic acid from A. wiedemanniana exhibited antiinflammatory activity. ${ }^{38}$ Sesquiterpene lactone extracts of the aerial parts of Anthemis aciphylla var. were evaluated for anti-inflammatory activity on carrageen-induced paw edema (acute model) and cotton pellet-induced granuloma (chronic model) in rats. ${ }^{39}$ The flavonoids apigenin and luteolin possess anti-inflammatory, carminative, and antispasmodic properties. Apigenin binds to GABA receptors and has a mild sedative effect. ${ }^{40}$ In vitro data: Chamazulene inhibited leukotriene synthesis in neutrophilic granulocytes and had additional antioxidant effects. ${ }^{41-43}$ Apigenin exhibited a dose- and time-dependent reversible effect on adhesion protein expression and inhibited up-regulation of specific leukocyte adhesion molecules on the endothelial cell surface. It also inhibits IL-1-a induced prostaglandin synthesis and TNF-a induced IL-6 and IL-8 production. Anthemis gayana flowers have analgesic and anti-inflammatory effects related to the presence of flavonoids and other terpene compounds.$^{44}$ Moreover, $A$. mirheydari could be considered as a new source for anti-cancer natural products due to the high cytotoxic effect of the plant extract in comparison with those measured for the standard cytotoxic agent, cisplatin $(4.2-9.4 \mu \mathrm{g} / \mathrm{mL}) .^{45}$

Ethanolic extracts of Anthemis gayana flowers have analgesic and antiinflammatory effects due to their rich contents in flavonoids and other terpene compounds. ${ }^{46}$

Studies revealed that $A$. triumfeti and A. tinctoria are rich in fatty acid content and flavonoids. ${ }^{47-49}$ In Turkey, Anthemis species are used in folk medicine due to their anti-inflammatory activities and antifungal activity too. ${ }^{35-37}$ The finding reflects the efficacy of Anthemis aciphylla in inhibiting the increase in the number of fibroblasts and the synthesis of collagen and mucopolysaccharide, which are natural proliferative events during granulation tissue formation. The revealed effect of the methanolic extracts on the inflammation process indicates that these agents act by affecting a time-delayed system in a similar fashion to glucocorticoids. ${ }^{50-52}$

\section{NEURO-PSYCHIATRIC ACTIVITY}

Antidepressants are expensive and exert adverse effects. Otherwise, traditional medicines are effective in treating this disorder. In Turkish folk medicine, infusions prepared from the flowers of Anthemis wiedemanniana Fisch. \& Mey induce sedation exerted by sesquiterpene lactones tatridin and tanachin responsible for the antidepressant activity of the flowers. ${ }^{53}$

In a previous study carried out by Paula Gardiner, she reported that, in mice, apigenin had a clear affinity for central benzodiazepine receptors. It inhibited competitively the binding of flunitrazepam, a benzodiazepine, but had no effect on muscarinic receptors, alpha 1-adrenoceptors, or the binding of muscimol to GABA receptors. Moreover, it had clear anxiolytic activity in mice without incidence of sedation or muscle relaxation effects at doses similar to those used for classical and standardized to $1 \%$ apigenin no anticonvulsant action was detected. Increasing dosages produced mild sedation and a reduction in ambulatory locomotor activity. ${ }^{54}$

\section{ANTIOXIDANT ACTIVITY}

\section{DPPH free radical scavenging activity}

Antioxidant activity is one of the most intensively studied subjects in essential oil research. An antioxidant is defined as a substance that considerably suspends or inhibits an oxidation process. On the other hand, the antioxidant activity is commonly determined via measuring the inhibition rate of an oxidation processes in the presence of an antioxidant. ${ }^{16} \mathrm{DPPH}$ is extensively used to determine the antiradical activity of a given compound or extract relative to a standard antioxidant, such as ascorbic acid. As a result, the free-radical scavenging activity of the hydrodistilled oil or the extract will be measured as a decrease in the absorbance of methanol solution of 2,2-diphenyl-1-picrylhydrazil (DPPH). Members of the tribe Anthemideae (Asteraceae) attract broad medicinal attention and are used for the treatment of many degenerative and infectious diseases due to their biologically active constituents. In addition, the inhibitory activity of Anthemis genus was studied toward soybean lipoxygenase using linoleic acid as substrate. It exhibited high inhibitory activity on soybean lipoxygenase due to its rich flavonoidal contents such as the study carried out on Anthemis tinctoria. $\mathrm{L} .{ }^{55}$ As a result, there is a strong correlation between amount of flavonoids and phenols of a particular plant part. Methanol extract of the flowers of Anthemis cretica L. demonstrated the highest antioxidant activity rather than leaves. Korina and Afanas'ev observed that flavonoids can prevent 
injuries caused by free radical by reacting with the reactive compound of the radical which could be achieved due to the high reactivity of the hydroxyl groups on the flavonoids. ${ }^{42,56,57}$

Studies showed that phenolic compounds might inhibit lipid peroxidation preventing formation of atherosclerotic plaques. ${ }^{58}$ Additionally, it has been reported that phenolic compounds inhibit the activities of several enzymes like the lipoxygenase, mitochondrial succinic oxidase and protein kinases as a result of their antioxidant effects. ${ }^{59}$

\section{ANTIBACTERIAL ACTIVITIES}

The antibacterial and antifungal activities of several extracts of Anthemis species are illustrated in Table 4.

The methanolic extract from Anthemis cotula flowers has antimicrobial activity against Gram-positive and Gram-negative microorganisms such as E.coli, Ps. aeruginosa and Salmonella species. ${ }^{59}$ However, the activity revealed against $E$. coli is the most significant when correlated with the folkloric use of the plant in the treatment of dysentery. The presence of eupatilin, jaceosidin and hispidulin might be responsible for the observed activities. In addition, A. altissima. L showed a wide antimicrobial spectrum in correlation with its flavonoidal contents rhamnetin and taxifolin. Moreover, the ethanolic extract obtained from Anthemis chia. L exerted a moderate effect on S. aureus explaining its use in Europe in skin inflammation. ${ }^{60}$ It had no antimicrobial effects neither on E. coli nor on P. aeroginosa. Currently further elucidation of the chemical structures of the phenolic constituents of some Anthemis species is carried out in order to evaluate the antimicrobial properties of individual flavonoid constituent.
The essential oils of A. aciphylla var. discoidea demonstrated significant antimicrobial activity against Gram-positive bacteria and Candida. albicans in correlation with their rich composition in monoterpenes and sesquiterpenes. ${ }^{60}$ The results obtained indicate high potential Anthemis palestina essential oil as bioactive oil for and medical purposes possessing antimicrobial, antioxidant and antiproliferative effects. They represent an affordable source of natural antifungal and antibacterial substances preventing the growth of fungi and bacteria which could be a valuable medicinal resource. Ethyl acetate and acetone extracts of A. coelopoda Var. bourgaei exhibited antimicrobial effects against most tested bacteria except for $S$. pneumoniae which explains its popular use in treating most infectious diseases in Turkey. ${ }^{64}$

\section{CONCLUSIONS}

This paper showed that sesquiterpene lactones and are highly distributed within the genus Anthemis and mostly the species cotula, wiedemannia and altissima respectively. While the flavonoids Jaceosidin, Eupatulin and Hispidulin are higly predominant as aglycones in Anthemis cotula, stiparum and nobilis and are effective in many ailments. In recent years, the number of new synthetic drugs entering the market has been low probably due to financial issues. In addition, synthetic drugs have been shown to be toxic. In order to overcome these challenges scientists have shifted their attention to natural products such as flavonoids and sesquiterpenes possessing potential health benefits. However, most of the research work has been on in-vitro studies. It is believed that renewed scientific efforts using human trials with pure flavonoids and the appropriate placebo will go a long way to provide new insight into the beneficial effects of flavonoids and which might eventually lead to the development of new class of bioactive compounds exerting a positive impact on

Table 4: Antibacterial activity of some Anthemis species

\begin{tabular}{|c|c|c|c|c|}
\hline \multirow{2}{*}{ Species } & \multirow{2}{*}{ Isolates } & \multicolumn{2}{|c|}{ Active against } & \multirow{2}{*}{ Ref. } \\
\hline & & Gram-positive & Gram-negative & \\
\hline A. cotula & Methanolic extract & $\begin{array}{c}\text { S. aureus } \\
\text { S. epidermidis Micrococcus } \\
\text { luteus } \\
\text { Streptococcus pneumonia } \\
\text { Pr.vulgaris }\end{array}$ & $\begin{array}{l}\text { E. coli } \\
\text { Ps. aeruginosa } \\
\text { Salmonella sp }\end{array}$ & 43 \\
\hline A. aciphylla var. discoidea & Essential oils from Aerial parts & $\begin{array}{c}\text { S. aureus } \\
\text { S. epidermidis Streptococcus } \\
\text { pneumonia } \\
\text { S. aureus }\end{array}$ & Candida. albicans & 61 \\
\hline A. altissima $\mathrm{L}$ & Essential oil & $\begin{array}{l}\text { S. aureus } \\
\text { S. epidermidis } \\
\text { B. subtilis }\end{array}$ & $\begin{array}{l}\text { E. coli } \\
\text { Ps. aeruginosa } \\
\text { Kl. pneumonia }\end{array}$ & 62 \\
\hline A. chia. $\mathrm{L}$ & Ethanolic extract & S. aureus & Candida. albicans & 63 \\
\hline A. palaestina & Essential oil & $\begin{array}{l}\text { S. aureus } \\
\text { S. epidermidis }\end{array}$ & $\begin{array}{c}\text { E. coli } \\
\text { Candida. albicans }\end{array}$ & 16 \\
\hline A. wiedemanniana & Essential oil & $\begin{array}{c}\text { S. aureus } \\
\text { S. epidermidis Streptococcus } \\
\text { pneumonia } \\
\text { S. aureus }\end{array}$ & $\begin{array}{c}\text { E. coli } \\
\text { Ps. aeruginosa } \\
\text { Kl. pneumonia } \\
\text { Candida. albicans }\end{array}$ & 64 \\
\hline $\begin{array}{c}\text { Anthemis } \\
\text { coelopoda Var. bourgaei }\end{array}$ & $\begin{array}{c}\text { Ethyl acetate extract } \\
\text { Acetone extract }\end{array}$ & $\begin{array}{c}\text { S. aureus } \\
\text { S. epidermidis Streptococcus } \\
\text { pneumonia }\end{array}$ & $\begin{array}{l}\text { E. coli } \\
\text { Ps. aeruginosa } \\
\text { Kl. pneumonia }\end{array}$ & 65 \\
\hline $\begin{array}{l}\text { aphylococcus } \\
\text { seudomonas }\end{array}$ & $\begin{array}{l}\text { Kl: Klebsiella } \\
\text { B: Bacillus }\end{array}$ & & & \\
\hline
\end{tabular}


the human health. All the previously mentioned compounds were responsible for the antioxidant and anti-inflammatory activities of this genus. Moreover, sesquiterpene lactones and sesquiterpenes as a whole represent a large and vastly important group of compounds, both to humans and to the plants themselves. A lot of efforts needed to be done by the researchers to find out more bioactive compounds of plants of genus Anthemis. Additional efforts are needed to explore possible incorporation of these compounds in pharmaceutical industry. Because of this, there are needs for widening public understanding of the importance of fruits and vegetable consumption, and thus better public image for vegetables containing them thus increasing their consumption. The reason is that they play a highly significant role in human health, both as part of a balanced diet and as pharmaceutical agents, due to their potential for the prevention and treatment of cardiovascular disease, diabetes, cancer and hypertension. Based on the antimicrobial results, it is possible to conclude that Anthemis extracts exhibited a broad range of antimicrobial activity to varying degrees. Particularly ethyl acetate extracts of Anthemis coelopoda Var. bourgaei, A. cotula, and A. wiedemanniana showed significant antibacterial activities and thus can be used as antimicrobial agents in new drugs for therapy of infectious diseases. More detailed phytochemical studies are, however, necessary in the future to identify the active principle(s) and exact mechanism(s) of action as there is a strong correlation between amount of phenols and flavonoids in particular plant part. This will lead to maintaining good health and wellbeing.

\section{ACKNOWLEDGMENT}

This work was supported by the Faculty of Pharmacy, Beirut Arab University.

\section{REFERENCES}

1. Güner A, Özhatay N, Ekim T, Baser KHC. Flora of Turkey and the East Aegean Islands. University Press, Edinburgh 2000;11

2. Ghafoor A. The Genus Anthemis L. (Compositae-anthemideae) in Arabia Peninsula: A Taxonomic Study. Pak J Bot. 2010;42:79-98.

3. Burim RV, Canalle R, Lopes JLC, Takahashi CS. Genotoxic action of the sesquiterpene lactone glaucolide $\mathrm{B}$ on mammalian cells in vitro and in vivo. Genet Mol Biol. 1999;22:401-6.

4. Saroglou V, Karioti A, Rancik A, Dimas K, Koukoulitsa C, Zervou M, et al. Sesquiterpene Lactones from Anthemis melanolepis and their antibacterial and cytotoxic activities. Prediction of their pharmacokinetic profile. Nat Prod. 2010;73:242-6.

5. Staneva J, Todorova M, Evstatieva L. Sesquiterpene lactones as chemotaxonomic markers in genus Anthemis. Phytochemistry. 2008;69:607 18.

6. Gonenc T, Argyropoulou C, Erdogan T, Gousiadou C, Juergenliemk G, Kıvçak B, et al. Chemical constituents from Anthemis wiedemanniana Fisch. and Mey. Biochem Syst Ecol. 2011;39:51-5.

7. Chadwick M, Trewin H, Gawthrop F, Wagstaff C. Sesquiterpenoids lactones: Benefits to plants and people. Int J Mol Sci. 2013;14:802-5.

8. Yang W, Luo Y, Aisa HA, Totahon Z, Mao Y, Xu L, Zhang R. Hepatoprotective activities of a sesquiterpene-rich fraction from the aerial part of Cichorium glandulosum. Chinese Medicine. 2012;7:1-7.

9. Davis PH, Mill R. R, Tan K. Flora of Turkey and The Aegean Islands (Supplement). 1988; 10.

10. Baytop T. Türkiye'de Bitkiler ile Tedavi, Geçmisteve Bugün. (Therapy with Medicinal Plants in Turkey, Past and Present), "2nd ed., Nobel Tip Kitabevleri, Istanbul. 1999.

11. Iscan G, Kırımer N, Kurkcuoglu M, Baser K H C, Demirci F. J Agric Food Chem. 2002;50:3943-6.

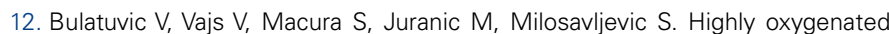
guainolides from Anthemis carpatica. J Nat Prod. 1997;60(12):1222-8.

13. Tuba MG, Esra KA, Ipec S, Tugce FE, Bijen K. Fatty acid composition and preclinical researches on Anthemis wiedemanniana Fisch. \& Mey: Discovery of a new anti-inflammatory agent. Pharmacognosy Magazine. 2014;10(37):53-60.

14. Yusufoglu HS, Alam A, Mohamad AS, Zaghloul AM. Anti-inflammatory and hepatoprotective activities of methanolic extract of Anthemis scrobicularis herbs. Phcog J. 2014;6(3):55-61.
15. Setzer WN, Schmidt JM, Noletto JA, Vogler B. Leaf oil compositions and bioactivities of tabaco bush medicines. Pharmacology online. 2006;3:794-802.

16. Bardaweel SK, Tawaha KA, Hudaib, MM. Antioxidant, antimicrobial and antiproliferative activities of Anthemis palestina essential oil. BMC Complement Altern Med. 2014;14:297.

17. Burim RV, Canalle R, Lopes JLC, Takahashi CS. Genotoxic action of the sesquiterpene lactone glaucolide $\mathrm{B}$ on mammalian cells in vitro and in vivo. Genet Mol Biol. 1999;22:401-6.

18. Bremer K. Asteraceae, Cladistics \& Classification. Timber Press, Portland Oregon. 1994;435-78.

19. Gach K, Długosz A, Janecka A. The role of oxidative stress in anticancer activity of sesquiterpene lactone. Naunyn schmiedebergs Arch Pharmacol. 2015;388(5):477-86.

20. Vajs. New linear sesquiterpene lactones from Anthemis cotula L. Biochemical Systematics and Ecology. 1999;33(1):97-102

21. John K, Hans B, Susannah A, Wilhelm B. Biosynthesis of Anthecotuloide, an Irregular Sesquiterpene Lactone from Anthemis cotula. Organic \& Biomolecular Chemistry. 2003;1(9):1503-8.

22. Peterson M, Abdullah $Y$, Benner J, Eberle D, Gehlen $K$, Janiak V. Evolution of rosmarinic acid biosynthesis. Phytochemistry. 2009;70(15-16):1663-79.

23. Ellis BE, Towers GH. Biogenesis of Rosmarinic acid in Mentha. Biochem J. 1970;118(2):291-7.

24. Sezgin C, Sergio R, Antonella MM, Rosa AR, Ismet U, Wanda K, Maurizio B. Sesquiterpene lactones from Anthemis wiedemanniana. Biochemical Systematics and Ecology. 2005;33:952-6.

25. Ivan VC, Ljubodrag V, Vlatka V, Vele, T, Slobodan M, Pedja Jk, Slobodan M. Sesquiterpene lactones from the aerial parts of Anthemis arvensis L. Biochemical Systematics and Ecology. 2006;34:303-9.

26. Staneva J, Todorova M, Evstatieva L. New linear sesquiterpene lactones from Anthemis cotula L. Biochem Syst Ecol. 2004;33:97-102.

27. Abou El-Ela M, Jakupovic J, Bohlmann F, Ahmed A, Seif El-Din K, Sabri N, El-Ghazouly M. Seco-germacranolides from Anthemis pseudocotula. Phytochemistry. 1990;29:2704-6.

28. Jordanka DS, Milka T, Ljuba E. New linear sesquiterpene lactones from Anthemis cotula L. 2005;33(1):97-102.

29. Bruno M, Rosselli S, Bondi ML, Gedris TE, Herz M. Sesquiterpene lactones of Anthemis alpestris. Biochemical Systematics and Ecolog. 2002;30:891-5.

30. Maria K, Anastasia, K, Spyros S, Helen S. Sesquiterpene lactones from Anthemis altissima and their anti-Helicobacter pylori activity. J Nat Prod. 2003;66(5):699-702.

31. Todorova M, Trendafilova A, Danova K, Dimitrov D. Phytochemical study of Anthemis rumelica (Velen.) Stoj. \& Acht. Biochemical Systematics and Ecology. 2011;39:868-71.

32. Yalda S. Sesquiterpenes and flavonoids of Anthemis odonstostephana var odontostepana. Chem Nat Compd. 2015;51(3):491-4.

33. Vujisic Lj, Vuckovic I, Vajs V, Tesevic V, Janackovic P. Sesquiterpene lactones and flavonoids from Anthemis ruthenica growing in Serbia. Chemistry of Natural Compounds. 2011;47(3):459-60.

34. Gonenc T, Argyropoulou C, Erdogan C, Gousiadou C, Juergenliemk G, Kıvçak B Skaltsa H. Chemical constituents from Anthemis wiedemanniana Fisch. \& Mey. Biochemical Systematics and Ecology. 2015;39(1):51-5.

35. Nikolova. High-mountain Bulgarian plant-free radical scavenging activity and flavonoid composition. 2014;33.

36. Talhouk R, El-Jouni W, Baalbaki R, Gali-Muhtasib H, Kogan J, Talhouk S. Antiinflammatory bio-activities in water extract of Centaurea ainetensis. Journal of Medicinal Plants Research. 2008;2(1):24-33.

37. Orhan I, Deliorman-Orhan D, Özçelik B. Antiviral activity cytotoxicity of the lipophilic extracts of edible plants and their fatty acids. Food Chem. 2009; 115:701-5.

38. Masterova D, Grancai1 Z, Grancaiova M, Pour K. A new flavonoid: tinctosid from Anthemis tinctoria L. Pharmazie. 2005;60:956-7.

39. Baltaci S, Kolatan E, Yilmaz O, Kivçak B. Anti-inflammatory activity of Anthemis aciphylla var. aciphylla. Turkish Journal of Biology. 2011;35(6):757.

40. Viola H, Wasowski C, Levi De Stein M. Apigenin, a component of Matricaria recutita flowers, is a central benzodiazepine receptors-ligand with anxiolytic effects. Planta Medica. 1995;61:213-6.

41. Safayhi H, Sabieraj J, Sailer ER, Ammon HPT. Chamazulene: An antioxidanttype inhibitor of leukotriene B-4 formation. Planta Medica. 1994;60:410-3.

42. George S, Panayiotis K, Stamatina G, Aris B, Spyros S, Helen S. In vitro anti-Helicobacter pylori activity of Greek herbal medicines. Journal of Ethnopharmacology. 2003;88(2-3):175-9.

43. Iscan G, Kırımer N, Kurkcuoglu M, Baser KHC, Demirci F. J Agric Food Chem. 2002;50:3943-6 
44. Maurizio B, Antonella, M, Sergio R, Muhammad S, Svetlana B. The Metabolites of the Genus Onopordum (Asteraceae): Chemistry and Biological Properties. Current Organic Chemistry.2011;15:888-927.

45. Amir R, Omidreza, F, Ranim M, Sajad S, Somayeh Z, Mehdi Z, Mehdli M. Cytotoxic activity and chemical constituents of Anthemis mirheydari. Pharmaceutical Biology. 2016;54:10

46. Shokoh H, Leila A, Ramesh M. Analgesic and anti-inflammatory effects of Anthemis gayana ethanolic extract in rats. Advances in Environmental Biology. 2013;7(14):4749-54

47. Safayhi H, Sabieraj J, Sailer ER, Ammon HPT. Chamazulene: An antioxidanttype inhibitor of leukotriene B-4 formation. Planta Medica. 1994;60:410-3.

48. Samadi N, Manayi A, Vazirian M, Samadi M, Zeinalzadeh Z, Saghari Z, et al. Chemical composition and antimicrobial activity of the essential oil of Anthemis altissima L. var. altissima. Nat prod Rs. 2012;26(20):1931-4.

49. Pavlovic M, Kovacevic N, Tzakou O, Couladis M. Components of cyclohexane extract of Anthemis triumfetti. Chem Nat Compd. 2007;43:512-4.

50. Baltaci S, Kolatan O, Yilmaz O, Kivcak B. Anti-inflammatory activity of Anthemis aciphylla var. aciphylla Boiss. Int J Pharm Sci Rev Res. 2013;21(1).

51. Stojkovic N, Stojkovic M, Marinkovi M. Polyphenol content and antioxidant activity of Anthemis cretica L. (Asteraceae). Oxidation Communications. 2014;37(1):237-46.

52. Khoshkhoo MEK, Nematollahi F. Flavonoid content of Anthemis tinctoria and its application for green synthesis of silver nanoparticles. Journal of Pharmacognosy and Phytochemistry. 2016;5(1):264-6.

53. Fatma TG, Mert I. Discovery of new antidepressant agents: In Vivo study of Anthemis wiedemanniana Fisch. \& Mey. Journal of Ethnopharmacology. 2018;226:11-6.

54. Viola $H$, Wasowski $C$, Levi De Stein $M$, et al. Apigenin, a component of Matricaria recutita flowers, is a central benzodiazepine receptors-ligand with anxiolytic effects. Planta Medica. 1995;61:213-6.
55. Paraskevi P, Diamanto L, Anastasia K. Phenolic compounds with antioxidant activity from Anthemis tinctoria L. (Asteraceae). Zeitschrift fur Naturforschung C. $2007 ; 62(5-6): 326-30$

56. Cushnie T, Hamilton V, Lamb AJ. Assessment of the antibacterial activity of selected flavonoids and consideration of discrepancies between previous reports. Microbiol Res. 2003;158:281-9.

57. Chadwick M, Trewin H, Gawthrop F, Wagstaff C. Sesquiterpenoids lactones: Benefits to plants and people. Int J Mol Sci. 2013;14(6):12780-12805.

58. Acquaviva R, lauk L. Natural polyphenols as anti-inflammatory agents. Front Biosc. 2010;S2:318-31.

59. Cao, G; Sofic, E; Prior, RL. Antioxidant and prooxidant behavior of flavonoids: structure-activity relationships. Free Rad Biol Med. 1997;22:749-60.

60. Quarenghi MV, Tereschuk ML, Baigorib MD, Abdala LR. Antimicrobial activity of flowers from Anthemis cotula. Fitoterapia. 2000;710-2.

61. Baser KH, Demirci B, Iscan G, Hshimoto T, Demirci F, Noma Y, Asakawa Y. The Essential Oil Constituents and Antimicrobial Activity of Anthemis aciphylla Boiss.var. discoidea Boiss. Chem Pharm Bull. 2006:54(2):222-5.

62. Samadi N, Manayi A, Vazirian M, Samadi M, Zeinalzadeh Z, Saghari Z, et al Chemical composition and antimicrobial activity of the essential oil of Anthemis altissima L. var. altissima. Nat prod Rs. 2012;26(20):1931-4.

63. Anti- inflammatory activity of Anthemis aciphylla var aciphylla Boiss. Turk J Biol 2011;35(6):757.

64. Kivcak B, Mert T, Saglam H, Ozturk T, Kurkcuoglu M, Baser KHC. Chemical composition and antimicrobial activity of the essential oil of Anthemis wiedemanniana from Turkey. Chemistry of Natural Compounds. 2007;43(1):4751.

65. Ismet U, Sezgin C, Mehmet O. Antimicrobial activity of Anthemis Coelopoda. Var. Borgaei Boiss, and Anthemis tinctoria Var. Pallida. Dc. Species having ethnobotanical features. Journal of Applied Sciences. 2005;5(4):639-42.

\section{GRAPHICAL ABSTRACT}
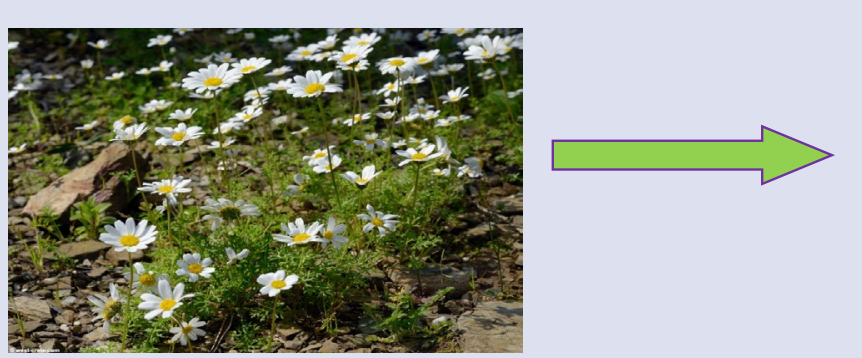

$\begin{aligned} & \text { Flavonoids } \text { Sesquiterpene lactones } \\ & \text { - Anti-inflammatory } \\ & \text { - Anti- oxidant } \\ & \text { - Anti-cancer } \\ & \text { - Anti-bacterial } \\ & \text { - Anti-fungal }\end{aligned}$

\section{ABOUT AUTHORS}

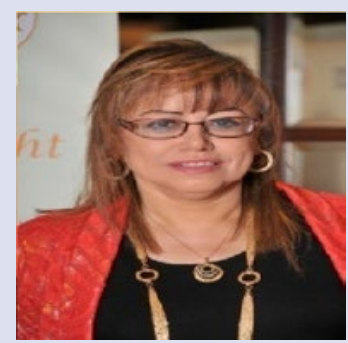

Prof. Maha Aboul-Ela is the Head of Pharmaceutical Sciences Department, Faculty of Pharmacy, Beirut Arab University. She has 30 years' experience in teaching (under and postgraduates courses) and research in Pharmacognosy and Phytochemistry and 17 years' experience in the field of QA in Higher education. Distinguishable Peer Reviewer at Egyptian National Organization for QA and accreditation. She has published more than 50 research articles in national and international scientific journals in the field of specialization. Attending many national and international conferences. Supervising more than 14 Master, Pharm.D and PhDTheses. She had PhD mission to West Germany for completion of practical studies and postdoctoral mission to School of Pharmacy, University of London, UK. She has Membership in the American Society of Pharmacognosy and the Egyptian Pharmaceutical Society. 


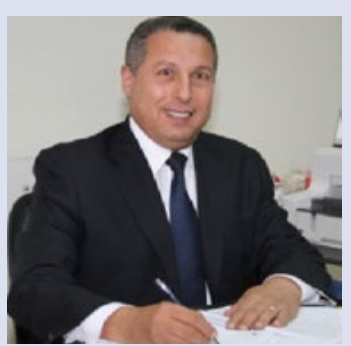

Prof. Abdalla El-Lakany is currently the Dean of Faculty of Pharmacy, Beirut Arab University. He has over 25 years of experience in teaching Phytochemistry, Pharmacognosy and Medicinal Plants and supervision of PhD, Masters and Pharm.D. theses. He is specialized in chemistry of natural products, with a special interest in diterpenoids, alkaloids and flavonoids. He has attended many national and international conferences and supervising more than 20 Master, Pharm.D and PhDTheses. Currently, he has a research project about alkaloids and their biological testing. He has published more than 55 scientific articles in high-impact journals.

Dr. Rima Boukhary Completed M. Pharm in Pharmacognosy in the year 2005 from Beirut Arab University. She has been awarded with PhD in 2017 from BAU. Presently working as an assistant professor in the area of Phytochemistry and Pharmacognosy. She has a vast experience of teaching and has several publications in the field of Pharmacognosy, Phytochemistry and herbal medicine.

Cite this article: Boukhary R, Aboul-EIA M, El-Lakany A. Review on Chemical Constituents and Biological Activities of Genus Anthemis. Pharmacog J. 2019;11(5):1155-66. 